\title{
Făgăraș as Jerusalem? Interethnic and interreligious ethos in Transylvania
}

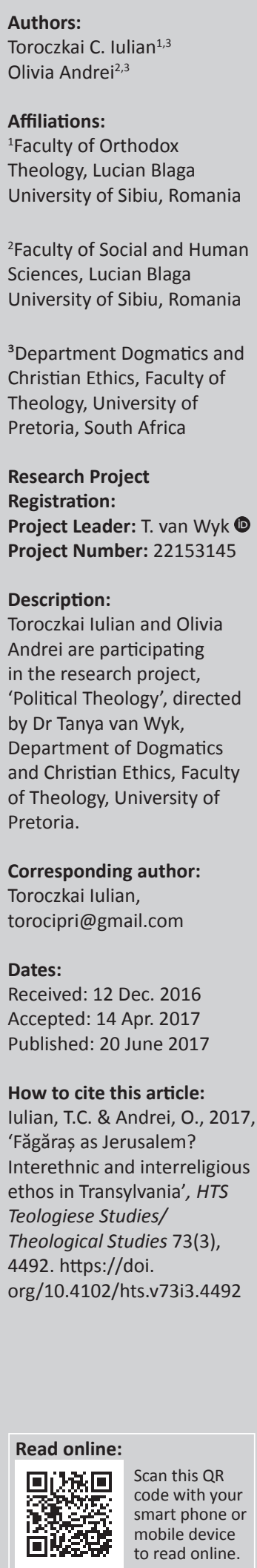

The study presents Transylvania as a space of ethnic-religious tolerance, having as a case study the image of the town Făgăraş, as depicted in Eginald Schlattner's novels. This space appears as one of a heavenly nuance, based on a long tradition of coexistence of the members of different ethnic groups and religions. However, the inter-war and post-war period means the emergence of new challenges posed by the confrontation with the harmful effects of the two ideologies: Nazism and Communism. In this way, the dramas of the socio-historical context interweave with elements forming young Eginald. They will remain a constant in the writer's life, offering Făgăraș the role of a forming educational array, with a paradigmatic value.

\section{Introduction}

\section{Motto: 'Fogorasch and Jerusalem - That really makes you laugh!'}

One of the most troubling biblical texts is represented by Psalm 136 (137 in the masoretic text) taken into Babylonian captivity (586-539 BC), in which the author remembers Jerusalem, linking the necessity of this act with the very price of his life. So sounds his mourning:

1. By the waters of Babylon, there we sat down, we wept when we remembered Zion.

2. We hanged our harps upon the willows in the midst there.

3. For there they that carried us away captive required of us a song, saying, 'Sing us one of the songs of Zion!'

4. How shall we sing the Lord's song in a strange land?

5. If I forget you, O Jerusalem, let my right hand forget her cunning!

6. If I do not remember you, let my tongue cleave to my neck, if I prefer not Jerusalem above my chief joy. (see English Standard Version)

Jerusalem was the capital of Canaan, and Canaan was 'The promised Land' of Yahweh - God to his chosen people, the Hebrew people. The fulfilment of Jeremiah's negative prophecies totally contrasts with the messianic, eschatological vision of the prophet Isaiah, who foretold a completely different side of Jerusalem. For him, Jerusalem was the place of Yahweh, because here was the mount of the Holy Temple; it will play a universal role for all of humanity: 'That mountain temple will be established over the mountaintops and will rise over the hills, and all nations shall flow in there' (Isa 2:2). This move of unnatural flow demonstrates the supramundane character of the mystical Jerusalem, the full presence of its divine holiness. As a consequence, 'the mountain of the daughter of Zion' will be marked by justice and honesty, harmony between humans and all creation. The day of Judgment, the coming of the Messiah, will mark the universal tolerance: 'They shall beat their swords into plowshares and their spears into pruning hooks ... and neither shall they learn war anymore' (Isa 2:4). Also, 'the wolf shall dwell with the lamb, and the leopard shall lie down next to the deer' (Isa 11:6).

The messianic hope over Jerusalem has not stopped for many centuries. At the beginning of the 13th century, when a Jewish poet, Judah al-Harazi, came from Spain on pilgrimage to the Holy Land, which was under Muslim domination, he uttered the following lament:

I would go every day to weep for Zion, mourning its destroyed palaces, climbing the Mount of Olives to prostrate myself before the Eternal. What a pain to see our holy yards turned into an alien temple. (Montefiore 2012:276)

The premise of departing this study is that, throughout his life, everyone has his own 'Jerusalem'. In the case of the writer and evangelical priest Norbert Eginald Schlattner (b. 1933; Short biobibliography in Olivia Spiridon 2012:307-309; Totok 2012:181-198), 'Jerusalem' was the city of Făgăraș (in German: Fogorasch). Here he spent much of his childhood and youth, here he formed

Copyright: (C) 2017. The Authors. Licensee: AOSIS. This work is licensed under the Creative Commons Attribution License. 
as a man, and this experience is described in this veritable Bildungsroman, The beheaded rooster (Schlattner 2001), which exposes the socio-historical and family context during 19421944. (The other two auto-biographical novels The red gloves and The piano infog moved to the 1957-1960 period, namely 1944-1951. See Schlattner 2003; 2005).

Beyond being a source of information of the German minority in a Romanian land in the 1940s, the first novel of the Schlattner's trilogy is particularly important because it shows this space as a defining one for multi-confessionalism and interculturalism - and this has been highlighted in several studies (to be seen especially Sass 2011:58-66). An image from the novel is very revealing: the walk of the author's father around the lake surrounding the medieval fortress of Făgăraş, on a Sunday afternoon. He greeted each one in his own language - Romanian, Hungarian, German or Saxon and, more than that:

he took off his hat to anyone. On his walk, he always took his hand to the head. In front of the Franciscan church where beggars were, on a good distance, he did not have time to put his hat on. (Schlattner 2001:35)

Although the Nazi ideology had appeared in the city, marking a part of the members of the Saxon minority, the father still refused to greet with 'Heil Hitler!' Or to put in the shop window tags that forbade Jews access (Schlattner 2001:35-36).

\section{Who is Eginald Schlattner?}

Norbert Eginald Schlattner, born in 1933 in Arad, spent his childhood in Vlăhiţa (Wlachendorf) Harghita county, in Brașov and in Făgăraș. During 1952-1953, he began to study theology; then he studied mathematics for a semester and nine semesters at the Faculty of Hydrology at the University of Cluj. Shortly before the graduation, in December 1957, he was arrested. Then, there were 2 years of detention in a cell in the prison building of security in Brasov, then 'the city Stalin'. In the lawsuit of the writers from Braşov in September 1959, Eginald Schlattner was one of the prosecution witnesses and the only one of them who was at that time in detention (details at Laza 2011:221-238).

He was sentenced because of 'omission of denunciation' and in 1960 he was released. After that, he first worked as a labourer in a tile factory in Făgăraș, then as a technician in constructions in Banat, and finally as a foreman in railway construction in Banat. After 1964, he was a technical designer in a factory near Sibiu. In 1969 he could complete the study that he began in 1953. He worked as a hydrologist engineer until 1973. He decided to make a radical change and so he resumed the study of evangelical theology. Since 1978 he is an Evangelical priest in Rosia (Rothberg) near Sibiu and since 1992 he was named evangelical missionary pastor for the 44 prisons in Romania, taking care of the evangelical prisoners from Aiud and Cluj jails.

His first novel, Der geköpfte Hahn, appeared in 1998 at Zsolnay publishing house in Vienna and knowing so far 10 editions, it reached the lists of bestsellers, being included in the manuals of German language. It was translated into Romanian by Nora Iuga in 2001 and then in Spanish and Hungarian. In 2007 it was made into a film by Radu Gabrea.

Schlattner's second novel, Rote Handschuhe (Vienna, Zsolnay 2000; Munich 2003) has seen four editions and has been translated into Polish, Romanian, Spanish and Hungarian, and in 2012 in Portuguese. Radu Gabrea screened the novel in 2010. The novel Klavierim Nebel (Vienna 2005) has reached its fourth edition and has been translated into Polish in 2009. In 2012 it was translated into Romanian and Spanish.

After the success of his first novel 'the literary tourism' in Rosia developed, Eginald Schlattner was portrayed in numerous television shows, scientific papers have been written at different universities across Europe and readings have been held by the author. In 2002 Eginald Schlattner was named 'Cultural Ambassador of Romania' and in 2004 received the Austrian Cross of Honor litteris et artibus of first class. Eginald Schlattner lives today in the parish house built in baroque style next to the medieval church in Roșia.

With an exalted lust to tell the novels, Eginald Schlattner presents the history of the 20th century with the help of the history of his family: the years 1942-1944 that for the German community in Romania ended up with 'the trap' between the states and the fronts (Der geköpfte Hahn); 1944 1951, a period of deportations, expropriations and insecurity (Das KlavierimNebel); 1957-1960, the years of detention (Rote Handschuhe).

\section{Saxons in Transylvanian: A brief history}

The history of Transylvania is one of a multitude of nations. Each ethnic group in part - either of Romanian, Hungarian, Hebrew or Saxon origin - has its own history, with different points of views, and partly with controversial interpretations regarding certain events or historical reports. Thus, on one hand, we find common points at all these ethnic traditions, which seem to justify the finding of a consensus in exposing the common history of Transylvania; on the other hand, we also find specific differences, inevitable, that explain the tensions that arose in this long history of coexistence.

Thus being part of the Saxons community in Transylvania, Schlattner was marked by its political, cultural and religious history. In this section, we do not try to offer a common history of Transylvania, nor an exhaustive one. We will refer only to the most important aspects regarding the German population in Romania (Saxons), because these are relevant to a better understanding of the mentality and the context that the author presents in his work.

About the history of Transylvanian Saxons it was stated that this intermingled since its beginnings with the history of the Church (Philippi 2008:75). Thus, the first documentary 
attestation refers to a document issued on 20 December 1191 in Rome entitled Ecclesia Theutonicorum Ultrasilvanorum. This reminds of the colonists settled in the present territory of Transylvania, as well as their right of 'priory' (praepositura). These Transylvanian Teutonic' are also mentioned in other documents, being sometimes called 'Flanders' and sometimes being designated with the collective name of 'saxones'. Thus, this last name will ultimately designate the Transylvanian Saxons. We notice their title of 'guests' (hospites), which means that they were invited, called to settle in a land that, although said desertum, does not mean that the country where they came it was a demographic desert. Other two issues are due to be mentioned: in accepting the invitation to resettle in Transylvania, the religious motivations played an important role, the colonisation of Saxons in Transylvania is synchronous with the Crusades; then, the ethnic diversity of the first settlers. These two aspects explain the dynamics of the history of the Saxons in the medieval period, marked by several key events: the confrontation with the Turks; the gradual detachment from the Hungarian royalty; the increase of the sense of solidarity of the Saxons community (symbolically illustrated by the location of the houses in the villages of Saxon type, very compact, 'yard by yard').

Domination over Transylvania, or over some parts of it, will vary: either under the Hungarians, the Turks or the Romanians (for a short period of time). Later, the emergence of the Reformation in Transylvania will produce important mutations (Philippi 2008:91). An important Transylvanian reformer was Honterus (approx. 1500-1549). In 1544 the small Catechism of Luther was published in Romanian, the language of the majority. On the other hand, already since 1579 the signs of the Catholic Counter-Reformation appear. It began an ideological, cultural, religious dispute and sporadically even military with long lasting effects.

Absolutist tendencies that characterised the domination of the Habsburgic Empire which dominates Transylvania, will be doubled in the 19th century by a trend of growing nationalist feelings. So now we find nationalist trends - with a religious substrate - both at the Hungarian, Romanian and Saxon, according to the principle of 'language and faith' (Philippi 2008:97).

The evangelical Church had an important word to say in the national self-assertion of the Saxon community, while the Orthodox and the Greek-Catholic (united) churches in that of the Romanian community:

But when the national feelings of the Romanians, for centuries loyal to the Austrian Emperor, turned slowly toward the national state in the desire to unite with the Romanians outside the carpathian arch (Moldavia and Wallachia, emphasis added), the Transylvanian Saxons developed, under the influence of the church, an idealistic self-consciousness of belonging to a nation of German culture (Kulturnation) understood in a spiritual sense. (Philippi 2008:98)

This explains the ease with which, after the 1920s, it occurred 'the infestation' of a part of the Saxon community of the national socialist ideology. If in the past, we find culturalreligious organisations as 'Gustav-Adolf Association', the 'Association of the German Schools' (Deutscher Schulverein) or the 'Associations of the evangelical women', and now it also must be mentioned a political association of 'the German ethnic group'.

The collapse of Nazi Germany in 1945 had serious repercussions on the German-speaking population in Romania. On 13 January 1945 all Transylvanian Saxons who could work and who were not under the arms (men between 17 and 45 years and women between 18 and 30 years, except those pregnant and who were breast feeding their babies) were raised from their homes to be deported to Russia for forced labour. It is estimated that their number was about 30 000, and within 5 years many of them will die of hunger, cold and diseases. Some of them came back in December 1949 or even later.

The abuses and the deprivations of the communist authorities will witness a turn in 1956, when the expropriated courts and lands of the peasants in 1945 will be given to their owners. Then many Saxon Germans hoped in a restoration of the earlier community life, but the evolution of the communist society was heading into another direction. It was a totally opposed process, as the Romanian state was combining the socialist doctrine of equality with the national socialist trend of ethnic homogenisation (details at Hasuleitner 2008). Any attempt to resistance was severely punished.

To these trends another one was added: for humanitarian reasons, the Federal Republic of Germany asked the socalled reunification of families, which made many people deported to Russia to persuade their loved ones to emigrate. Certainly, a strong argument in this exodus was of economic nature: while the situation in the communist Romania was deteriorating rapidly, the Federal Republic of Germany had a growing economy. Another aspect that should be added is that the communist-nationalist state charged money for each ethnic German that left (similar to the situation of another ethnic group in Romania, the Hebrew one) (Philippi 2008:100). The associations of emigrants from Germany also exerted pressure to increase the number of emigrants:

The continuous emigration, however, had negative effects on the fundamental conditions of the life of Saxons in Transylvania, and on maintaining their identity. And it has crept a feeling of helplessness before an unstoppable current, which had to be obeyed when in fact you did not want that. Then in 1990, when the borders were opened (after the bloody revolution of December 1989, when the totalitarian regime of the dictator Nicolae Ceaușescu was overthrown, emphasis added), the first wave tore apart in Germany, more than half of the nearly 100,000 evangelicals Saxon still remaining. (Philippi 2008:100-101)

The situation of the Saxon community in Transylvania was a precarious one. The remaining survivors also feel as the survivors of a catastrophe, thing that Schlattner spoke about in some of his interviews given to Romanian or foreign 
journalists. Is there hope for a revival? Is it a topic beyond that surpasses the purpose and the limitations of our study?

\section{A walk through Eginald Schlattner's Făgăraș - From earth to heaven?}

What kind of place was the Făgăraş of Eginald's childhood? Was it the embodiment of 'heaven on earth', the perfect illustration of the heavenly Jerusalem that the authors of psalms or some Old Testament prophets spoke of? Could it be the equivalent of Augustine's ideal city, as suggested by the author of a study (Kory 2008)? More than likely the author himself would revolt at such an idea, and more rebellious would be his aunts, who always insisted on the superiority of the German race or the other races' inferiority to the former. Despite the tolerance that marked the land of Făgăraş, we are told that 'Romanians and Hungarians in Transylvania are enemies from father to son like the cat and the dog' (Schlattner 2001:91).

And yet ... the comparison between Făgăraș and Jerusalem is not so out of place, as it appears even in a discussion of a book chapter ('Around the city'). The discussion is held by a grandfather, namely the Saxon priest of the city, who - as we will see - makes young Eginald begin to see the realities around him with new eyes.

The conversation between grandfather and the priest Fritz Stamm begins by evoking a happening that the first one went through during the First World War (1914-1918) - after the ship sank, he rescued himself by floating with a barrel of rum. After a while, serious existential issues are discussed, such as the care of God, the meaning of life, the reality and the need of a miracle (everything on a simple, natural tone, marked by the scepticism of grandfather before the priest's manifestation of faith). Step by step, the discussion reaches the present situation when it seems that any physical and spiritual landmark was gone:

You could rely on none and nothing, that was it. Neither on men nor on powers, not even on your own feelings. Nor on the exterior appearance of our little strengthened town nor on our solid house. (Schlattner 2001:102)

This uncertainty makes the priest to 'anticipate' - as it was characterised by grandfather - the destruction of Făgăraș like the biblical cities of Sodom and Gomorrah, and Jerusalem, too. Why this? Without saying it directly, we can guess why: the loss of values, of stability, the damage of the divine order harmony of this 'city that has everything that makes a small town to be a small town'. But as the Bethlehem of Judea, where the Messiah was born, Făgăraş has a tradition that transforms it into a great spiritual centre, despite its reduced terrestrial size. The proof: the name of those who live in, for 'it is the name that gives the rank' ... It can meet in Făgăraş, as in any other town, tailors, curates, farmers, who have royal or noble names: Kaiser, König etc. Their origin goes back centuries ago, and this thing is true for the members not only of the Saxon community but also of Hungarian (Bathory) or
Romanian (e.g. Knight Bogdan SerbanAurel of Voila) community. Among them, until recently, it seems that there were good cohabitation relationships, required by the label of true noblemen (Pătuleanu 2000; Vogelaar 2006:482-483). Their rank, their nobility, was particularly a spiritual one, which made the place they lived together for centuries a space of diversity, but not the one that divides, but joins. It is this 'unity in diversity' that the priest refers to when he lists various places from Făgăraș with a symbolic value (Schlattner 2001):

Think only at the names of streets, names of buildings, of churches and of cemeteries: how much color, how much diversity! For instance, the street of the Greeks, of the Gypsies, the Lutheran Street, where the German school and the Evangelical Church is located, the Armenian Church, the Hungarian united Church, the Hungarian reformed Church, Franciscan Monastery, Romanian Orthodox Archpriest Parish District, the Greek Catholic Episcopate of the Romanians united with Rome ... the Hebrew Synagogue ... and the great sensation: the Turkish steam bath ... the strange villa of the Prefect ȘHebre of Voila in an eclectic style between a Portuguese monastery and a Buddhist pagoda, but without any stylistic inconsistencies. ... The priest passed now at the outskirts of the town, in the Alut meadow there's the Hebrew cemetery, a place that deserves to be seen, even if it is located behind the Green Street. (pp. 106-107)

(I confess that the name 'the Green Street' does not mean anything to me, especially when I went there on my way to Olt river ... What I could not understand, as a child, was that at my insistent questions where this name came from, my grandmother felt lost all the time and she rushed me and refused to give me any information, for even my great confusion ... I had to read Schlattner's novel to find the answer to the question: 'Yes, we were blessed with a Green Street, where in front of some houses a red lantern is hung !' ... Yes, it was a street with brothels!)

The scepticism of grandfather's remarks to the arguments made by the priest is not at all unnecessary. Even the latter regrets that 'the town might disappear from the earth as Jerusalem once. It represents an eminent form of life, even anticipates something of the new Jerusalem'. And to this statement, the grandfather reacts sceptically, too, the comparison Făgăraș - Jerusalem seems to him totally misplaced 'Fogorasch and Jerusalem - that really makes you laugh!' (Schlattner 2001:107).

The priest opposes, insisting that the situation of this town was one of crying, not one of laughing ... Just as Jesus deplored the fate of Jerusalem, so it must be deplored the current state of Făgăraș, one of decline, as the largest cities of Sodom and Gomorrah, Jerusalem or Rome. Again, if grandfather sees, 'crusty', a likeness of Făgăraş with the biblical city of perdition, Babel, the priest refers to it as a potential 'new Jerusalem'; if grandfather believes that to resemble Făgăraș with Jerusalem is equivalent to a mirage girl, a vain illusion, the priest Stamm once again highlights the spiritual quality of this Transylvanian space - 'a place of equality, of brotherhood and peace' (Schlattner 2001:108). 
This is the moment when young Eginald enters the scene, called by the priest to support his assertions. Until then, grandfather, without being convinced, asks for real evidence, namely a physical place that embodies the metaphysical realities to which the priest, apparently, utopically had referred to. Paradoxically, this 'geometric place' of perfection is represented, hic und nun, by the swimming pool of the town (Schlattner 2001):

Every summer afternoon, at the swimming pool by the river, where you can meet almost all the people from Fogorasch, almost naked, as once in paradise and probably as in the new Jerusalem. All nations and races, every class and profession, all ages and sexes gather here in a full reconciliation. For me that place by the river becomes a model and a symbol. There can be met alpha and omega, the beginning and the end of the Bible .... (p. 109)

At the evocation of this image, the grandfather repeatedly responds with a hiccup, proof of the illness he suffered from, which the author called: hydrophobia. If for grandfather it is a physical reaction, for the priest it is a spiritual one: the space of peace, of harmony 'in the earthly form', disappeared. And the priest added: 'But we missed the chance that God has given us. Because at that time we did not recognize what served our peace. Jesus Christ cries again for us' (Schlattner 2001:109).

\section{Nazism and Communism: Ideology against humankind}

The child Eginald is annoyed by these words; he cannot understand where the disharmony is from, as the swimming pool is still there, and he still goes with his friends ... Only when the priest points out that not all of them are still there, that most of the Jews avoid the place, only then the author - he, 'a young polished Hitlerite' - begins to recognise the new reality, it seems that he crosses the initiating threshold of maturity. And, he, as Adam in paradise had begun to realise the mistake, ashamed ('I was ashamed that it had not given more attention to this amazing fact'). But blindness was still strong: the hope of final victory was still present, seeming to be (the new and) the only factor of stability in the new reality. Anticipating, it will require the total collapse of the world of childhood, the confrontation with another totalitarian ideology (the Communism) so that Eginald Schlattner will be awakened to the brutal reality. This chasing from heaven will not be an easy thing at all. In the novel The red gloves, while he is led to jail, the passage through the Făgăraş of his childhood, the author says that it no longer arouses in him any nostalgia (Schlattner 2003:12). And yet, in the space of isolation - which is exactly at the antipode of the freedom space in the area of Făgăraș - and not infrequently certain events or things make him involuntarily think of the childhood spent in Făgăraş. Finally, we mention two examples: when he wants to go on a hunger strike and he is refused this gesture of revolt; the guards force him to eat, remembering him their Hungarian maid who forced a goose to eat corn to become fat; finally it fell dead - 'suffocated by too much good' (Schlattner
2003:36) (the terrible symbolic image of Communism! See more in Dumitru 2011:43-48 and Predoiu 2008:401-412). Finally, summoned for questioning, Schlattner remarks to the secret police agent (Securitatea) that, in the so-called era of equality between gender classes, he was wearing a black suit made especially for him by a tailor. Again, his mind flies to his own tailor-made suit, made by the craftsman Bardocz from Făgăraș ... Where this nostalgia from: 'Formerly. Formerly, think automatically, in the days of exploiters, before the liberation from the fascist yoke' (Schlattner 2003:45).

Reading the novel will dearly demonstrate that the new 'liberating' regime does not encourage freedom or nostalgia. Thus, Eginald Schlattner is forced to stay with Făgăraș or Jerusalem present in the only place where no one can take it away: his heart. From here he will take the face and the name of the place where he lives - and where he refuses to leave from - the priest and the writer: Roșia (near Sibiu) (Binder 2001). That the two ideologies of the 20th century, Nazism and Communism, have marked the Transylvanian space having consequences until today, something that we can see in the emotional interview offered by Schlattner himself (Schlattner 2006; 2010) - and that, to understand him in his real dimension, we should design him mentally in the Jerusalem of his life!

\section{Conclusion}

The history of Transylvania provides many examples of both religious tolerance and inter-ethnic conflicts. The testimony that Eginald Schlattner offers in his novels is a realistic and credible one, or just an idealised projection of the space of his childhood? The answer is not easy to give (Gombocz 2014). Clearly, his perspective on Făgăraş could be easily included in the cycle of an utopia. On the other hand, there are elements that present 'the dark side' of this space. Schlattner's intention is obvious: to present a clear contradiction between the reality of the 'old' world when harmony reigned among citizens (of social, cultural, religious nature etc.), and the world of the 'new', marked by differences that are based on extremist ideologies (Nazism and later Communism). These new ideologies which invade the heavenly space cause the damage of the order, of the former harmony; they disturb the peace of the people who lived in a community.

Worthy to note is that this community was an extremely heterogeneous one. There could be found not only members of different Christian traditions but also members of other religions (e.g. Jews). Tolerance and intercommunion are everlasting values, and the way in which ethnic and religious difficulties have been overcome and harmonised in the recent past in Transylvania can also become a model for our contemporary world. In the multi-ethnic and multi-religious context, marked by dynamism, the 'Transylvanian ecumenical ethos' (Oancea 1988) - exposed in his work by Eginald Schlattner - could be considered a possible model in other regions of the world, where ethnic intolerance and religious fundamentalism generate conflicts and even genocide. 


\section{Acknowledgements}

\section{Competing interests}

The authors declare that they have no financial or personal relationships which may have inappropriately influenced them in writing this article.

\section{Authors' contributions}

T.C.I. and O.A. equally contributed to the research and writing of this article.

\section{References}

Binder, R., 2001, 'Literatura ca izbăvire?', România literară 25, 20-21.

Dumitru, A., 2011, 'Zum Zeitverständnis in Eginald Schlattners Roman Rote Handschuhe', Bulletin of the Transilvania University of Brasov, Series IV: Philology and Cultural Studies 2, 43-48.

Gombocz, I., 2014, 'Eine Nußschale auf hoher See - Eginald Schlattners siebenbürgische Romantrilogie', Zeitschrift für Siebenburgische Landeskunde 37, 159-180.

Hasuleitner, M. (ed.), 2008, Vom Faschismus zum Stalinismus. Deutsche und andere Minderheiten in Ostmittel- und Südosteuropa 1941-1953, IKGS, München.

Kory, B.P., 2008, 'Fogarasch als Abbild der Civitas Dei. Eginald Schlattners Debütroman: Der geköpfte Hahn im Zeichen der Multikulturalität', Temeswarer Beiträge zur Germanistik 6, 387-400.
Laza, L., 2011, 'Relațiile cu Securitatea a doi dintre acuzații din procesul scriitorilor germani de la Brașov. Dosarele de rețea ale lui Wolf von Aichelburg și Georg Scherg', Caietele CNSAS 1-2, 221-238.

Montefiore, S., 2012, Jerusalem: The biography, Vintage Books, New York.

Oancea, D., 1988, 'Ecumenismul în gândirea teologică transilvăneană', in Contribuţii transilvănene la teologia ortodoxă, pp. 342-356, Sibiu.

Pătuleanu, C., 2000, Die Begegnung der rumänischen Orthodoxie mit dem Protestantismus (16. bis 20. Jahrhundert), unter besonderer Berücksichtigung des bilateralen theologischen Dialogs zwischen der Evangelischer Kirche in Deutschland und der Rumänischen Orthodoxen Kirche (1979-1998), Verlag Dr. Kovacs, Hamburg.

Philippi, P., 2008, '800 de ani din istoria sașilor din Transilvania', in D. Brandes, V. Grăjdian \& O. Lukacs (eds.), Scurtă istorie a Bisericilor și comunităților religioase din Transilvania, pp. 75-102, Presa Universitară Clujeană, Cluj-Napoca.

Predoiu, G., 2008, 'In den Zwängen der Zeit. Überleben und Leben in Schlattners Roman Das Klavier im Nebel', Temeswarer Beiträge zur Germanistik 6, 401-412.

Sass, M., 2011, 'Literatură versus film. Peisaj socio-politic şi intercultural din Transilvania în ecranizarea romanului lui Eginald Schlattner', Cocoşul decapitat Transilvania 3-4, 58-66.

Schlattner, E., 2001, Cocoșul decapitat, Humanitas, București.

Schlattner, E., 2003, Mănușile roșii, Humanitas, București.

Schlattner, E., 2005, Klavier im Nebel, Zsolnay, Wien.

Schlattner, E., 2006, 'Dialog cu Eginald Schlattner', Revista Literară Vatra 1-2, 34-42. Schlattner, E., 2010, 'Adevărul, un proces între dreptate și îndurare', Orizont 1, 4-6.

Spiridon, O. (ed.), 2012, Deutsche Erzähler aus Rumänien nach 1945, Curtea Veche, București.

Totok, W., 2012, 'Empathie für alle Opfer. Eginald Schlattner, ein Leben in Zeiten diktatorischer Herrschaft', Halbjahresschrift für südosteuropäische Geschichte, Literatur und Politik 1-2, 181-198.

Vogelaar, H., 2006, 'An ecumenical journey in Romania: Orthodox protestant relationships since 1989', in The research annuals of Al. I. Cuza University of Iaşi XI, pp. 479-508, The Alexandru Ioan Cuza University Publishing House, Iasi. 